\title{
Effect of lysozyme on lactate production of Streptococcus mutans
}

\author{
Yukihiko Mishiro, Kazuko Kirimura, Masako Morikawa and Minako Tsunosue \\ Department of Biochemistry (Chief: Prof. Yukihiko Mishiro), Nippon Dental University, \\ 1-9-20 Fujimi, Chiyoda-ku, Tokyo 102, Japan
}

[Accepted for publication: April 20, 1982]

Key words: lysozyme / Streptococcus mutans / lactic acid

Human whole saliva contains significant quantities of lysozyme, but very few species of oral bacteria, including streptococci, have been shown to be lysed directly by lysozyme ${ }^{1)}$. Sugishima ${ }^{2)}$ has found an inhibitory factor for the lactate production of Streptococcus salivarius ATCC 9758 in the salivary supernatant and has reported that the factor is non-dialysable, heat labile at $\mathrm{pH} 7$ (but heat stable at $\mathrm{pH} \mathrm{3)}$ and is similar to lysozyme. Koyama $^{3)}$ has demonstrated that Streptococcus sanguis ATCC 10557 treated with hen egg white lysozyme (HEWL) shows a decrease in lactate production without any reduction in turbidity. On the other hand, the lysis of normally resistant streptococci has been achieved through sequential treatment with lysozyme and either detergents or high concentrations of $\mathrm{NaCl}^{4)}$. Coleman et al. ${ }^{5)}$ have shown that many cariogenic and noncariogenic oral streptococci can be lysed by lysozyme and sodium lauryl sulfate (SLS), and loss of viability (colony-forming unit) of Streptococcus mutans BHT can be induced by lysozyme alone. The treatment of strain BHT with lysozyme alone also results in extensive degradation of the cell wall as shown under electron microscopy ${ }^{6)}$. It is generally accepted that the importance of lysozyme in the oral cavity may not only reside in its lytic potential but also in its bactericidal effects which are not dependent upon cell lysis ${ }^{7}$.

The purpose of this investigation was to compare the effects of HEWL on lactate production among Streptococcus mutans strains (serotypes a, b, c and d described by Bratthall $\left.{ }^{8}\right)$ in the salivary supernatant (SS), whose lysozyme was inactivated by heating. After rinsing the mouth with deionized water, naturally occurring human whole saliva was collected in a test tube. Then the saliva was centrifuged at $12,000 \mathrm{~g}$ for 10 minutes. The supernatant was heated at $100^{\circ} \mathrm{C}$ for 30 minutes and used as a culture medium for Streptococcus mutans strains (AHT, BHT, FA1, JC2, PK1, Ingbritt and $\mathrm{B} 13)$. These strains were inoculated in TEP bouillon and cultured at $37^{\circ} \mathrm{C}$ for 18 hours. The cells were harvested by centrifugation at $12,000 \mathrm{~g}$ for 10 minutes and washed three times with $10 \mathrm{ml}$ of $6 \mathrm{mg} / \mathrm{ml} \mathrm{NaCl}$. The washed cells were suspended in the $\mathrm{NaCl}$ solution. The optical density of the suspension at $660 \mathrm{~nm}$ was adjusted to 0.60 adding the additional $\mathrm{NaCl}$ solution. HEWL (Seikagaku Kogyo, Tokyo) was dissolved in 6 $\mathrm{mg} / \mathrm{ml} \mathrm{NaCl}$ so as to make the concentration of $2 \mathrm{mg} / \mathrm{ml}$ immediately before use. One milliliter of $4 \mathrm{mg} / \mathrm{ml}$ glucose, $0.5 \mathrm{ml}$ of $2 \mathrm{mg} / \mathrm{ml} \mathrm{lysozyme} \mathrm{or} \mathrm{of} 6 \mathrm{mg} / \mathrm{ml} \mathrm{NaCl}$ and $0.5 \mathrm{ml}$ of the bacterial suspension (BS) were added to $2.0 \mathrm{ml}$ of SS and incubated at $37^{\circ} \mathrm{C}$ for 4 hours under aerobic condition (unshaken). The lactic acid produced was determined by the method of Barker-Summerson ${ }^{9)}$. The results obtained are shown in Fig. 1. The open bars show the amount of lactic acid produced by each strain in SS during 4 hours of incubation. The shaded bars indicate the lactic acid produced in SS in the presence of HEWL at a final concentration of $250 \mu \mathrm{g} / \mathrm{ml}$. Among these 7 strains, the lactate productions of serotype $b$ strains, BHT and FA1, were apparently inhibited by the addition of HEWL. However, serotype a 


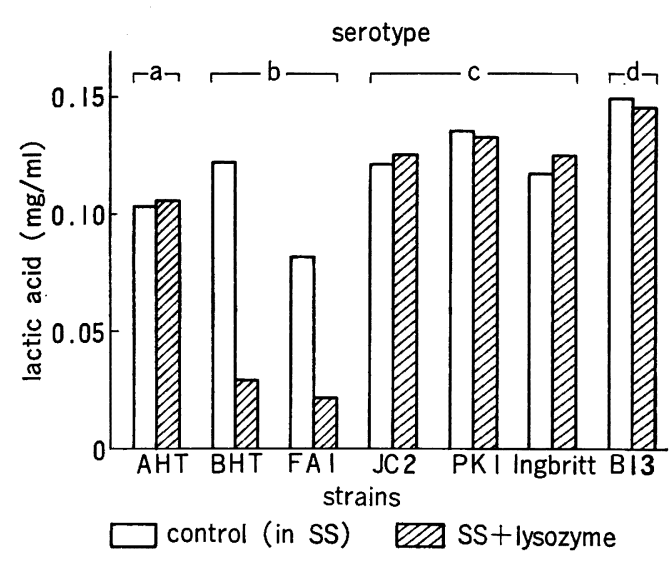

Fig. 1 Production of lactate by a variety of Streptococcus mutans strains exposed to lysozyme $(250 \mu \mathrm{g} / \mathrm{ml})$ in SS.

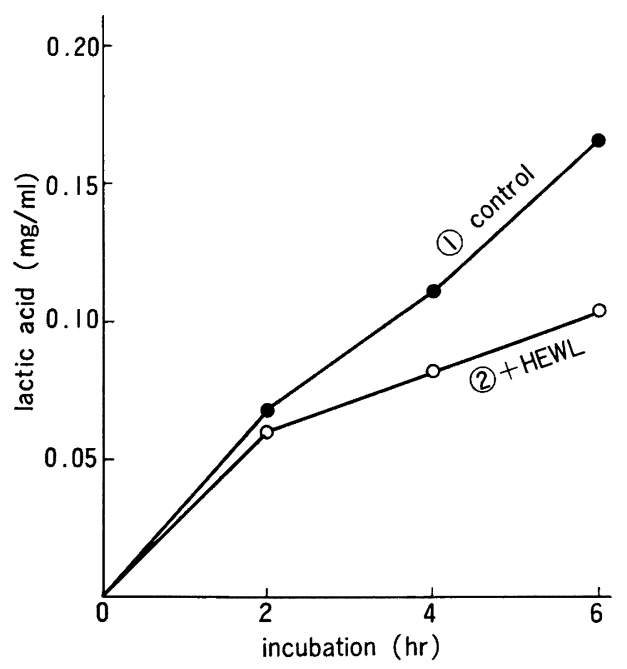

Fig. 2 Lactate production of Streptococcus mutans FA1 in (1) control (SS $2 \mathrm{ml}$, BS $0.5 \mathrm{ml}, 4 \mathrm{mg} / \mathrm{ml}$ glucose $1 \mathrm{ml}, 6$ $\mathrm{mg} / \mathrm{ml} \mathrm{NaCl} 0.5 \mathrm{ml}$ ), (2) + HEWL (SS $2 \mathrm{ml}, \mathrm{BS} 0.5 \mathrm{ml}, 4 \mathrm{mg} / \mathrm{ml}$ glucose $1 \mathrm{ml}, 240 \mu \mathrm{g} / \mathrm{ml} \mathrm{HEWL}$ in $6 \mathrm{mg} / \mathrm{ml}$ $\mathrm{NaCl} 0.5 \mathrm{ml}$ ).

strain (AHT), serotype c strains (JC2, PK1, Ingbritt) and serotype $d$ strain (B13) were not affected in their lactate production by HEWL. Fig. 2 shows the lactate production of Streptococcus mutans FA1 in SS containing $1 \mathrm{mg} / \mathrm{ml}$ glucose and $30 \mu \mathrm{g} / \mathrm{ml} \mathrm{HEWL}$.
The test mixtures were incubated at $37^{\circ} \mathrm{C}$ for 2, 4 and 6 hours. When HEWL was added to SS, the lactate production of strain FA1 was reduced during incubation. It is conceivable that lysozyme can inhibit lactate production of some strains at a concentration of physiologic levels in saliva.

Some investigators have observed that serotype b strains are the most susceptible to lytic action of lysozyme, but other strains also lyse well ${ }^{5,6)}$. Our data indicate, however, that only $b$ strains reduced the lactate production ability by lysozyme. The differences may exist in the characteristics of the outer layer, cell wall and cell membrane, among various strains.

\section{References}

1) Gibbons, R. J., Stoppelaar, J. D. and Harden, L.: Lysozyme insensitivity of oral bacteria. IADR Program and Abstracts of Papers, No. 113, 1965.

2) Sugishima, Y.: Inhibitory effect of salivary factor (lysozyme) on the lactate production of a strain of Streptococcus salivarius. Jap. J. Oral Biol. 13: 159-173, 1971. (in Japanese)

3) Koyama, T.: The effect of lysozyme on the lactic acid production of microorganisms. Jap. J. Oral Biol. 13: 204-224, 1971. (in Japanese)

4) Pollock, J. J., Katona, L. I., Goodman, H., Cho, M. I. and Iacono, V. J.: Bacteriolysis of Streptococcus mutants BHT by lysozyme and inorganic anions normally present in human saliva. Arch. Oral Biol. 26: 711-716, 1981.

5) Coleman, S. E., van de Rijn, I. and Bleiweis, A. S.: Lysis of cariogenic and noncariogenic oral streptococci with lysozyme. J. Dent. Res. 50: 939-943, 1971.

6) Bleiweis, A. S., Craig, R. A., Coleman, S. E. and van de Rijn, I.: The streptococcal cell wall: Structure, antigenic composition, and reactivity with lysozyme. J. Dent. Res. 50: 1118-1129, 1971.

7) Pollock, J. J., Iacono, V. J., Goodman-Bicker, H., MacKay, B. J., Katona, L. I., Taichman, L. B. and Thomas, E.: The binding, aggregation and lytic properties of lysozyme. In Microbial Aspects of Dental Caries (edited by Stiles, H. M., Loesche, W. J. and O'Brien, T. C.), p. 325-352, Information Retrieval Inc., Washington, D.C. and London, 1976.

8) Bratthall, D.: Immunofluorescent identifica- 
tion of Streptococcus mutans. Odont. Revy.

23: 181-196, 1972.

9) Barker, S. B. and Summerson, W. H.: The colorimetric determination of lactic acid in biological materials. J. Biol. Chem. 138: 535$554,1941$. 